\title{
FORMA DE PENSAR E EMANCIPAC̣ÃO PÓS-MODERNAS DO HUMANO
}

\author{
Postmodern Form of Thinking and Emancipation of the Human \\ Forma de Pensar y Emancipación Posmodernas de lo Humano
}

MANUEL MOREIRA DA SILVA

\begin{abstract}
Resumo: Este artigo consiste numa explicitação da forma de pensar (Denkform) e da concepção de emancipação emergentes desde, aproximadamente, meados do século XX; em rigor, da estrutura de pensamento mediante a qual os indivíduos organizam sua experiência de mundo ou intentam emanciparse no presente. Busca-se mostrar em que medida o humano pós-moderno pensa e age em um mundo que não se configura mais como um cosmos natural (no caso, o antigo e medieval) ou enquanto um mundo representado (o moderno e contemporâneo, em vias de dissipação), ou mesmo enquanto linguagem (este ainda subordinado à representação), mas enquanto imagem. Verificam-se, enfim, os desafios e os modos de superação daqueles, bem como suas consequências, para a pessoa humana, de um pensar que deixou para trás a segurança da comunidade natural dos antigos e a liberdade formal da autoconsciência plenamente cônscia do espírito certo de si dos modernos. Um pensar que, todavia, também não se deixa levar por nenhuma confiança cega na linguagem do presente; mas que, ao contrário, a modula segundo as imagens nas quais pensa e se move em sua igualmente oscilante emancipação.
\end{abstract}

Palavras-chave: Pensar em imagens; antipodianos; pensamento forte; pensamento fraco

\begin{abstract}
This article aims an explanation of the form of thinking (Denkform) and the conception of emancipation that emerged from around the middle of the twentieth century; strictly speaking, the structure of thought through which individuals organize their world experience or attempt to emancipate themselves in the present. It seeks to show to what extent the postmodern human thinks and acts in a world that no longer shapes itself as a natural cosmos (in this case, the ancient and medieval) or as a represented world (the modern and contemporary, in the process of Dissipation), or even as language (this still subordinated to representation), but as image. Finally, the article examines the challenges and ways of overcoming them, as well as their consequences, for the human person, of a think that has left behind the security of the natural community of the ancients and the formal freedom of self-consciousness fully aware of the spirit sure of itself in the modernity. A thought which, however, does not allow itself to be led by any blind trust in the language of the present; but, on the contrary, modulates it according to the images in which it thinks and moves in its equally oscillating emancipation.
\end{abstract}

Keywords: Thinking in images; antipodeans; strong thought; weak thought.

Resumen: Este artículo consiste en una explicación de la forma de pensar (Denkform) y de la concepción de emancipación emergentes desde, aproximadamente, mediados del siglo XX; en rigor, de la estructura de pensamiento mediante la cual los individuos organizan su experiencia de mundo o intentan emanciparse en el presente. Se busca mostrar en qué medida el humano posmoderno piensa y actúa en un mundo que no se configura más como un cosmos natural (en el caso, el antiguo y medieval) o en cuanto un mundo representado (lo moderno y contemporáneo, en vías de comunicación disipación), o incluso como lenguaje (éste todavía subordinado a la representación), pero como imagen. Se verifican, en fin, los desafíos y los modos de superación de aquellos, así como sus consecuencias, para la persona humana, de un pensar que ha dejado atrás la seguridad de la comunidad natural de los antiguos y la libertad formal de la autoconciencia plenamente cónsia del espíritu correcto de sí de los modernos. Un pensar que, sin embargo, tampoco se deja llevar por ninguna confianza ciega en el lenguaje del presente; pero que, por el contrario, la modula según las imágenes en las que piensa y se mueve en su igualmente oscilante emancipación.

Palabras Clave: Pensar en imágenes; antipodianos; pensamiento fuerte; pensamiento débil.

\section{Considerações preliminares}

Este trabalho investiga a forma de pensar (Denkform) atual e o seu influxo na concepção de emancipação hodierna; mais precisamente, discute a estrutura de pensamento ${ }^{1}$ pela qual o humano, no

1 O termo 'estrutura de pensamento' é utilizado aqui em seu sentido técnico, tal como introduzido em filosofia por André de Muralt (2008), passim, ver especialmente, p. 4955. Veja-se, a respeito, Florido (2000), p. 195-216. sentido do que é próprio do ser humano, organiza sua experiência de mundo ou intenta emancipar-se no presente. O trabalho, portanto, consiste na explicitação do confronto entre o ideal de emancipação moderno, fundado na consciência da liberdade à qual o indivíduo acede na medida em que alcança o saber de si enquanto o que é livre em si e para si, e a concepção pós-moderna de emancipação. Essa, fundada na oscilação, no acontecer plural e no desgaste 
do real'2 ${ }^{2}$ mais que na oscilação, na pluralidade, e por fim no desgaste do próprio "princípio de realidade", tal como constatados e expostos por Vattimo ${ }^{3}$.

Partindo da distinção entre a concepção pós-moderna de emancipação e aqueles ideais, o trabalho descreve os elementos estruturantes destes, a estrutura de pensamento que, em cada um, se mostra operante, assim como os limites da mesma. Desse modo, esclarece em que medida o indivíduo pós-moderno pensa e age; mais precisamente, delineia a estrutura de pensamento na qual e mediante a qual ele, a um tempo, conforma o seu mundo. Um mundo que não se configura mais como o cosmos natural antigo e medieval, nem como o mundo representado moderno ou mesmo o mundo estruturado como linguagem contemporâneo, ainda subordinado à representação e, em vista disso, igualmente em vias de dissipação; por conseguinte, à diferença destes, um mundo configurado enquanto imagem. O indivíduo pós-moderno conforma, pois, um mundo em que pensar e agir, assim como cognição e emoção, permanecem aquém e além da cisão moderna entre o mundo natural e a subjetividade transcendental; mas também de sua crítica pós-moderna inicial, que se limitou a naturalizar o transcendental.

O trabalho verifica, enfim, os modos de superação daqueles ideais, bem como as consequências de um pensar que deixa para trás a segurança da comunidade natural e a liberdade formal da autoconsciência plenamente cônscia do "espírito certo de si mesmo"4. Um pensar que, entretanto, também não se deixa levar por nenhuma confiança cega na linguagem estruturante do contemporâneo; mas que, ao contrário, a modula segundo as imagens nas quais pensa e se move em sua igualmente oscilante emancipação. Essa mostra-se assim não porque se funda em um princípio de realidade ou no desgaste deste e sim, ao contrário, no desgaste do real ele mesmo; bem como na imagem móvel de um instante para nós eterno, o pensar no presente.

\section{Pensar no presente, instante eterno cuja imagem móvel se nos doa}

Tempos revoltos esses, cujo mero acontecer nos proporciona existir. Este, aqui e agora, em seu multiverso - ao ser e, portanto, estar aí - deixa, por

2 Pela expressão "oscilação, acontecer plural e desgaste do real", o autor pretende demarcar a sua posição em torno do real. Trata-se de um confronto com a concepção de Vattimo, indicada imediatamente a seguir, no mesmo período, no corpo do texto, e com certas teorias que assumem o real, a um tempo, como fugidio e singular, sem relação ou ligação entre si de seus acontecimentos propriamente ditos, qualquer que seja o horizonte de sua consideração. Para essas teorias, o real nunca chega a constituir o que desde os medievais tardios tem se designado 'realidade'.

3 Ver, a respeito, Vattimo (1992), p. 13ss.

4 A expressão "o espírito certo de si mesmo" ("der seiner selbst gewisse Geist") é de Hegel e tem a ver com "a certeza de si mesmo" do espírito ou do $\mathrm{Eu}$, pela qual, por exemplo, em René Descartes, a modernidade se instaura. Com "a certeza de si mesmo", Hegel pretende resolver o problema da cisão do saber em seu ser-á e, assim, apresenta a reconciliação do espírito consigo mesmo como o ser-aí do Eu expandindo-se em dualidade. Ver, Hegel (1807/1988), p. 394ss (Fenomenologia do espirito, 2. ed. São Paulo: Loyola, 2003, $\S \S 596-671$, p. 410-457). sua impermanência, imediatamente de sê-lo. Vivenciamos, cada um, modos de ser ou de existir plenos de incerteza e ignorância; as quais, ainda, não soubemos valorar de maneira adequada, isso ocorre por nos mantermos presos a uma forma de pensar hoje decadente ou a outra, que só pode afirmar-se na decadência daquela ou em seu enfraquecimento. Essas formas de pensar consistem, respectivamente, no pensar por conceitos abstratos ou representações próprias dos modernos, iniciado por volta dos séculos XIII e XIV, e no pensar por imagens, já praticado por Nietzsche e Heidegger, mas originário do cristianismo em suas origens ${ }^{5}$. Prática e origem estas que conformam uma nova proposição do pensar por imagens no último quarto do século XX; quando o pensar por imagens é designado pensamento débil, justamente em razão de contrapor-se ao pensar por conceitos, então chamado pensamento forte, no sentido de debilitá-lo ou enfraquecê-lo ${ }^{6}$.

Não obstante, para aquém e além dessas duas formas de pensar, nosso presente mostra-se estruturado em imagens digitais, contrasta-se, pois, com o mundo estruturado como linguagem da modernidade tardia, ainda persistente, e o da representação, dos primeiros modernos; o qual sobrevivera até os inícios do século XX, quando caducara sem volta. O contraste ora manifesto, porém, não é senão a expressão de consequências primais, resultantes da ascensão do pensar por conceitos abstratos e de sua queda - mais bem, enfraquecimento - no quadro teórico do pensamento débil ou indigente, pura e simplesmente por imagens, entendidas como conceitos abstratos ou formais, ou ainda representações, destituídos de objeto, precisamente, de ser objetivo ou representado, isto é, de objetividade, de conceito objetivo ou de realidade objetiva. 'Conceito objetivo' ou 'realidade objetiva', no sentido preciso do significado de uma representação em geral ou, de modo mais estrito, a título de exemplo: do conteúdo da espécie inteligível ou do conceito formal do ente, como entre os medievais tardios; da ideia ou da representação mental, como em Descartes; enfim, do conteúdo especulativo das formas de pensar puras, como em Hegel. Desse modo, cessam toda explicação e toda interpretação, mais exatamente, toda compreensão; emerge, enfim, o singular em sua plena idiotia ${ }^{7}$, esse cujo entendimento-de-ser, enquanto ser-aí, torna-se o problema fundamental ${ }^{8}$. Consagra-se, pois, uma espécie de vitória de Pirro contra toda e qualquer forma de abstração; em suma, contra a própria realidade ${ }^{9}$ e o assim chamado princípio de realidade.

Eis a razão principal de o tempo presente, como já constatara Heidegger, não poder dispensar-se de empreender esforços para desencadear uma

\footnotetext{
5 Ver, a respeito, Boulnois (2008), passim.

6 Veja-se, Vattimo (2010), p. 12-28; Vattimo (1993), p. 5-6, p. 19ss; p. 110ss. Para a noção de pensamento forte, na perspectiva do pensamento débil, ver Eco, L'antiporfirio, p. 52ss.

7 Sobre este ponto, ver Rosset (1977).

8 Tal problema move praticamente todo o Ser e tempo de Heidegger. Ver, M. Heidegger (2012), citado conforme a sigla SuZ (Sein und Zeit), seguida dos respectivos parágrafos e a paginação correspondente à primeira edição (1927): SuZ, § 26, 120ss; § 28, 133-134, e §§ seguintes; § 43, 200ss).

9 Para uma compreensão introdutória do termo 'realidade' e de sua história, veja-se Argote (2006), p. 145-180.
} 


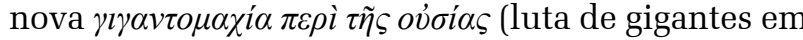
torno da substância ou do ser ${ }^{10}$; dessa vez, contudo, entre o pensamento forte e o pensamento fraco. Dessa $\gamma \imath \gamma \alpha v \tau o \mu \alpha \chi i \alpha$, entretanto, ao contrário das intenções expressas de Heidegger e, depois deste, das de Vattimo em desvelar o sentido de ser e em tornar explícito um novo ideal de emancipação ou de pertença entre ser e ser-aí, o que se constata ao longo de todo o século XX não é senão a emergência de gerações cada vez mais crescentes de antipodianos. 'Antipodianos' constitui-se aqui em um termo emprestado de Rorty, com o qual este autor se refere a um hipotético planeta, denominado Antipodéia, cujos habitantes seriam, em tudo, opostos aos terráqueos; em especial, não saberiam que possuiriam mentes e, assim, nada que pudesse ser denominado psique, consciência, espírito, alma separada do corpo ou afins ${ }^{11}$. Em vista disso, pode-se dizer que, em rigor, antipodianos não explicam, nem interpretam, logo não entendem, nem compreendem, apenas constatam ou, no melhor dos casos, denotam; conforme constatara Umberto Eco, no que tange ao experimento de Rorty, os antipodianos não são capazes de entender nem mesmo o significado de uma frase ${ }^{12}$. Em todo caso, nossos antipodianos não são os antipodianos do outro lado da Galáxia; são, contudo, bem mais reais do que se poderia pensar inicialmente e apresentam, portanto, um desafio real e genuíno a educadores, psicólogos, psicanalistas e. por que não, a filósofos.

Isso agrava em muito o problema acima aludido, sobretudo porque este se refere na verdade ao problema da relação mente-corpo, bem como do lugar da consciência e das representações mentais nos dias atuais. Sejam os antipodianos reais ou imaginários, eles não são capazes de entender nem mesmo o significado de uma frase, a explicação a mais plausível parece ser a de que eles não pensam por conceitos ou representações, dos quais, para assim pensar, necessitariam estar conscientes, em especial de si mesmos enquanto seres pensantes; sendo o próprio saber de que possuem mentes um resultado daquele pensar, ao qual também se designa pensamento abstrato. Mesmo destituídos de mentes, ou de um lado interior, consistindo em puro e simples Dasein, os antipodianos pensam; daí Rorty aceitar que eles, embora não pensem abstratamente, mediante representações mentais de uma consciência, pensam in concreto, isto é, sem inferências conscientes e, de algum modo, conforme certos existenciais em sentido próximo ao pensar por imagens heideggeriano ${ }^{13}$, desenvolvido por Vattimo no quadro de sua ontologia hermenêutica. $\mathrm{O}$ fato importante é que, em assim procedendo, embo-

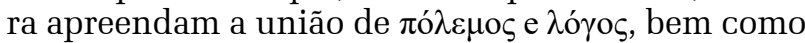
se aproximem ao ser e à liberdade frente às sensações, os antipodianos perdem completamente de vista a apreensão da união do elemento cognoscitivo e do emocional; logo, do teorético e do prático,

10 Ver, Heidegger, SuZ, $\S 1,2$. Heidegger refere-se aí diretamente à expressão utilizada por Platão em $O$ sofista, 247, referindo-se por sua vez à questão do que se pretende significar quando se utiliza o termo 'ente' (on). Veja-se, Platon, Le sophiste, 244a e seguintes.

11 Ver, Rorty (1994), p. 81ss.

12 Ver, Eco (1992), p. 335ss.

13 Rorty (1994), p. 84. permanecendo única e exclusivamente no poiético. Quando, enfim, sem o sentido próprio do ético ou sem sabedoria prática, sua busca pelo sentido de ser e pela liberdade não pode senão soçobrar.

Ao mesmo tempo em que aparecem os antipodianos, porém, emerge ainda uma forma de pensar que não é por categorias ou conceitos abstratos constituídos de realidade objetiva e nem por imagens resultantes da retirada de tal realidade daquelas categorias ou daqueles conceitos, uma forma de pensar que se configura como um pensar em imagens. Este pensar, por sua vez, mostra-se como sinal de um importante acontecimento, cuja presença, apesar do crescente fenômeno dos antipodianos, e mesmo no interior de sua geração - algo cada vez mais passível de constatação - é interessante observar; um acontecimento, portanto, que se dá a conhecer para aquém e além da cisão do universal e do singular; aqui, respetivamente, o ser humano como consciência ou autoconsciência e como ser-aí. O acontecimento disso que pode ser designado o abrangente ${ }^{14}$, liberto das malhas do universal abstrato que o aprisionara desde seu primeiro surgimento e pela ditadura do particular, ou do singular, que, de quando em quando - como no caso dos antipodianos e do pensamento débil, enquanto pensar por imagens - se contrapõe ao universal, buscando, entretanto, pura e simplesmente enfraquecê-lo. Tal acontecimento, porém, só se dá a conhecer no quadro teórico-prático de um pensar nele mesmo, quer dizer, no referido acontecimento; por conseguinte, no quadro de um pensar no abrangente, cuja forma própria não é senão o pensar do próprio abrangente.

Pensar no abrangente significa pensar de modo não conceitual, portanto, sem representações abstratas ou abstrações formais e, em vista disso, sem fazer do pensar, enquanto este se contrai dentro de si mesmo, um centro de consciência separado e distinto, como, por exemplo, a alma o é em relação ao corpo em Descartes. Da mesma forma, o pensar no abrangente também não é um pensar imagético, de certo modo fundado na imaginação ou no imaginário; por conseguinte, não faz das imagens, quaisquer que sejam elas, substitutos dos conceitos ou das representações - ou, o que é o mesmo, não faz dos sentidos substitutos dos significados ou necessita inverter sua relação entre si - como o faz o pensar por imagens ${ }^{15}$. Ao contrário, situando-se aquém e além do sentido e do significado, enquanto modos secundários - posteriores ao primário, o dado sensível, ou o signo, que é a Coisa mesma - de apresentação desta em suas respectivas dimensões (o juízo, o conceito ou a representação e o dado), o pensar no abrangente reconhece no significante (enquanto imagem psíquica, como tal distinta de qualquer representação e mesmo de toda significação), mais propriamente em sua independência em relação ao signo (aqui, o dado primário), ao sentido e ao significado, o modo adequado, livre, pelo qual ele mesmo se dá ${ }^{16}$. Na medida, pois, em que não é

14 Para uma primeira aproximação ao tema, no sentido aqui tematizado, ver Silva (2016), p. 221-254.

15 Ver, a respeito, Heidegger (1978). Ver também, J. A. Mac Dowell (1993), p. 77ss; em especial, p. 80, nota 231.

16 Devido ao escopo do presente trabalho, não se tematizará aqui o sig- 
um pensar por conceitos abstratos e nem um pensar por imagens, o pensar no abrangente se configura como um pensar em imagens; este que se reconhece duplamente em Aristóteles.

Como um pensar em imagens, o pensar no abrangente assume a sensação como seu ponto de partida concreto. Contudo, aqui, a sensação não

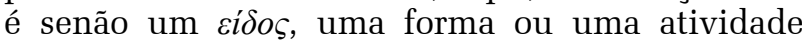

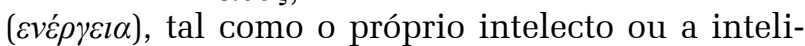
gência mesma: esta, segundo Aristóteles, é a forma das formas; aquela, a forma dos sensíveis ${ }^{17}$. Neste sentido, na medida em que - como forma das formas - o intelecto se mostra enquanto forma da sensação, ainda que de modo indireto, ele se apresenta igualmente como forma dos sensíveis. Isso não significa senão que Aristóteles assume - como fundamento de seu pensar - a homologia da inteligência e da sensação, sobre a qual se assenta a sua concepção de que, embora pensamentos não sejam imagens, não se pode pensar senão em imagens ${ }^{18}$. Esse também o fundamento de sua concepção do

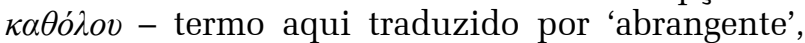
para distingui-lo do universal abstrato da tradição lógica e metafísica posterior - como um elemento concreto, comum a tudo que é o caso, isto é, o singular $^{19}$. Em vista disso, para o estagirita, se tem que "proceder do abrangente ao singular; porque o todo é mais cognoscível segundo a sensação, e o abrangente é de certo modo um todo, pois o abrangente compreende muitas coisas como partes" ${ }^{20}$. O abrangente, então, se dá a conhecer como princípio do singular, do que é o caso: porque abrangente, porém, ele não é um princípio causal - transcendente, emanente ou imanente -, nem transcendental ou regulativo, nem mesmo hermenêutico ou interpretativo; porque abrangente, ele não sai de si, não está fora, nem dentro de nenhum principiado - não assume, pois, nenhuma função de princípio; não principia ou procede, nem consuma ou converte, tão só permanece dentro de si em eterna expansão e contração. Não obstante, como elemento concreto comum a tudo que é o caso, o abrangente se evidencia como o princípio estruturante de todos os singulares; de modo que pensar no abrangente não é senão pensar nessa estrutura dinâmica, na medida em que ela está presente naqueles e, assim, conforma-se como a dimensão originária, manente ${ }^{21}$, que

nificante, o sentido ou o significado como os modos ou sob os aspectos ora aludidos. Não obstante, de modo apenas aproximativo, o que aqui se impõe, em certo sentido, se identifica com a concepção lacaniana do significante e, em rigor, com a imagem no pensamento mítico, ou mesmo no pensamento selvagem, tal como retratado por Lévi-Strauss.

17 Aristóteles (2006), III, 8, 432a, 1-3.

18 Aristóteles (2006), III, 7, 431b2ss; III, 8, 432a, 3-14.

19 Ver, a respeito, Merlan (1975), p. 173ss.

20 Aristote (1956), 1, 184a22-26.

21 Como se pode depreender do contexto imediatamente acima, no corpo do texto, o termo 'manente' refere-se aqui à manência (ou à moné, em grego), termo que por sua vez exprime a permanência do princípio nele mesmo, dentro de si, e, em rigor, o fato de que, nesse caso, o princípio não exerce mais a função de princípio; quer dizer, a função de princípio causal ou de elemento constitutivo das coisas ou dos entes. À concepção que afirma essa dimensão originária, antes, a mais originária, podemos designar filosofia da manência, que reivindica para si a herança da mistagogia do Uno e da filosofia especulativa pura, desenvolvidas de modo respectivo por Proclus e por Hegel. A filosofia da manência se limita ao imanifesto, ao manente, aquém e além da manifestação e do manifesto, e assim ao que os abrange e envolve em todos os seus aspectos; em suma, ao abrangente. Contudo, porque o neles se expande e deles se contrai. Desse modo, ao permitir a verificação dessa expansão e dessa contração, a um tempo nos singulares e no abrangente, o pensar em imagens e o pensar no abrangente se apresentam como um só e mesmo pensar.

Urge explicitar passo a passo esse novo pensar, em suma: o novo início do pensar que já se nos mostra, assim como a concepção de emancipação que nele e por ele se nos mostra. Um novo início que, precisamente, só o é para nós e na medida em que nos despojamos das formas exteriores do pensar, as quais fazem do pensar ora um instrumento que degrada seu próprio elemento em o tornando cada vez mais e mais abstrato, ora um meio passivo que o mantém inerte e, portanto, sem condições de tocar ou perceber a si mesmo ${ }^{22}$. Instrumento e meio passivo que, nos dias de hoje, se dão a conhecer sob as respectivas nomenclaturas do pensar por conceitos abstratos e do pensar por imagens, precisamente, do pensamento forte e do pensamento fraco.

\section{Pensar em imagens e emancipação pós-moderna}

Como já se aludiu mais acima, o que se denomina aqui 'pensar em imagens' tem sua origem na tematização aristotélica do pensar, a qual se dá ainda em um quadro teórico-filosófico em que não existiam conceitos, universais abstratos ou representações mentais ${ }^{23}$. Apesar desse aspecto comum, o pensar em imagens ora emergente não se dá em imagens enquanto estas seriam "como que sensações percebidas, embora desprovidas de matéria" 24 e assim fixadas pela memória sensível ou corporal, a memória das lembranças do passado ${ }^{25}$. Antes disso, o pensar em imagens hodierno pensa em imagens digitais, fixadas, por seu turno, através de uma memória igualmente digital, que se constitui como uma estrutura mediante a qual a imagem se conforma enquanto imagem e se conserva em um recipiente todo virtual e autônomo em relação ao intelecto. Caso em que este, justamente por isso, a um tempo, é livre para acessá-lo e permanece livre para todo e qualquer uso possível de tais imagens,

saber do imanifesto, para nós, se inicia pelo saber do manifesto, este não é senão a imagem, o aparecimento ou o fenômeno (do grego phainómenon, particípio presente de phainestai, vir à luz) resultante de certa manifestação que, ainda para nós, e, justamente por isso, consiste no iluminar de estruturas que, pelo entrelaçamento dos elementos estruturantes aqui designados como ser, conceber e haver, ao se forjarem pela expansão e contração do princípio, em rigor, da archké ou do início, indicam o imanifesto, tornando-o passível de reconhecimento, embora indireta e parcialmente, pelas imagens conformadas pela iluminação de tais estruturas.

22 Essa a situação do pensamento pelo menos desde a época de Hegel, que a descreveu de modo preciso na Introdução à sua Fenomenologia do espírito (Hegel, 1988), p. 57-58. (Fenomenologia do espírito, op. cit., § 73, p. 71-72).

23 Sobre este ponto, veja-se, Hartmann (1964). Em outro registro, para o início da representação como tal na história do ocidente, mais precisamente em Duns Scotus, e da representação mental, no caso em Descartes, ver, Muralt (2008), p. 153-196

24 Aristóteles (2006), III, 8, 432a9-10.

25 A expressão 'lembranças do passado' caracteriza aqui a memória sensível em Aristóteles, a partir de uma distinção de G. Sondag, em sua Introduction [a L'Image] (in D. Scot, 1993, p. 7-107, p. 10-11), do Intelecto em Duns Scotus enquanto "o lugar das espécies" e, assim, como "uma memória que, pelo fato que ela é o reservatório vivente de tais espécies, pode ser nomeada uma 'memória intelectual', por oposição à memória das lembranças do passado". 
assim como de tal recipiente, que passa a ser um verdadeiro conceptáculo.

Desse modo, o processo de conformação digital da imagem é completamente livre em relação aos sentidos e mesmo ao intelecto enquanto faculdades determinadas. Isso porque, em sentido próprio, ele não fixa imagens (como figuras ou formas estáticas), em rigor, figurativa ou espacialmente determinadas, em suma, enquanto lócus de certa informação visual; mas apenas fornece pontos de referência, isto é, informação descritiva, a partir dos quais as imagens mesmas, multifacetárias por natureza, conformam-se em sua natureza própria. Informação visual e informação descritiva constituem os dois tipos de informação em jogo no processamento digital de imagens: a primeira, superficial, se exprime na imagem vista na tela do computador, tal imagem consiste no resultado ou na síntese de determinadas operações que, na informação visual, permitem a visualização de um modelo matemático; este constitui a informação descritiva, profunda, e se apresenta como base da primeira enquanto modela ou representa o que é visualizado na imagem vista na tela do computador ${ }^{26}$. Neste sentido, porquanto pensa em imagens digitais, o pensar em imagens pode ser comparado ao processamento digital de imagens na medida em que realiza determinadas operações sobre imagens, operações que resultam por seu turno, elas mesmas, em imagens; não como as máquinas, enquanto estas levam a termo análise de objetos definidos pela imagem e a geração de modelos matemáticos desses objetos, mas enquanto se apropria da estrutura noética em que isso ocorre, em especial o chamado paradigma dos quatro universos. Segundo tal paradigma é preciso sair do mundo real, que consiste em sinais contínuos, e instalar-se no mundo digital, discreto: a passagem de um a outro se inicia pelo universo físico, no qual se concentram os objetos do mundo real; uma vez que desses objetos se formulam descrições abstratas, os mesmos trasladam-se para o universo matemático, e deste, na medida em que as descrições abstratas são capazes de representação e assim permitem a discretização dos sinais contínuos, elas instalam-se no universo da representação e, portanto, no mundo digital. Contudo, falta ainda a codificação do sinal discretizado ${ }^{27}$ na memória do computador, processo realizado mediante uma estrutura de dados; algo passível no âmbito do universo de implementação, conformando assim o que se designa memória digital.

Em vista disso, a memória digital distingue-se da memória intelectual, surgida com o processo de produção, ou antes, de fixação das espécies inteligíveis no e pelo intelecto, assumindo este o lugar de repositório delas; distingue-se também da memória sensível, tematizada por Aristóteles e então concebida como memória das lembranças do passado. Esta circunscreve-se assim ao elemento temporal,

26 Para uma visão geral do processamento de imagens no âmbito da computação gráfica, veja-se Scuri (2002).

27 Termo utilizado aqui a partir do verbo 'discretizar', usado em estatística e matemática para exprimir a individualização, a divisão ou a partição de uma unidade contínua em unidades individuais (discretas), com o intuito de diminuir a complexidade dos mesmos e, assim, facilitar cálculos. especialmente ao plano de imanência cujo referencial, para o passado e para o futuro, não é senão o presente em que transcorre a ação, isto é, o momento em que se faz uso das lembranças nela em jogo; um uso que, todavia, de maneira alguma se serve de conceitos ou de universais abstratos. A memória intelectual, por seu turno, transcende o elemento temporal e, com isso, o plano de imanência que o tem como referencial; mostra-se, por conseguinte, a partir de um elemento atemporal, como que em um presente absoluto ou eterno (em rigor, abstrato), e, em consequência, em um plano de transcendência: situação em que os conceitos e os universais abstratos encontram aí o seu lugar adequado e se mostram então, em rigor, transcendentais. Ao contrário destes, a memória digital não se move em um plano de imanência e muito menos em um plano de transcendência, mas antes em um plano de manência ${ }^{28}$; esse no qual imanência e transcendência se anulam e, com isso, a memória tout court se libera tanto das lembranças do passado, quanto das espécies inteligíveis produzidas e fixadas pelo intelecto como determinações formais ou abstrações e, então, ao fim e ao termo, como que se desterritorializa. A memória digital, portanto, no ente humano corporeamente determinado, não é o repositório das imagens (determinadas) que ela conforma, como é o caso do cérebro na memória sensível e na intelectual; assim como nestas, na memória digital não há especificamente imagens (visuais, auditivas etc), sejam lembranças do passado, espécies inteligíveis ou representações que antecedem o ato de conhecer, há tão somente uma certa estrutura de conformação de tais imagens (não-linear e por isso de processamento mais rápido), que é a estrutura de pensamento hoje operante em boa parte das novas gerações. Por isso, no ente humano, a memória digital se serve indistintamente da memória das lembranças do passado, portanto da memória sensível ou corporal, e da memória intelectual - ambas libertas, respectivamente, da imaginação e do entendimento como faculdades separadas e, com isso opostas entre si como um único e mesmo suporte para as imagens então processadas.

No ente humano, porém, as memórias são perecíveis, tanto as de curto quanto as de longo prazo; por esse motivo, sobretudo essas últimas, necessitam de um repositório em que se estendam, no qual sejam armazenadas, podendo então ser acessadas, bem como processadas. Neste sentido, tal como a memória sensível e a memória intelectual se instituíram e se consolidaram a partir de repositórios nos quais se estendiam, como a oralidade e a escrita, também a memória digital se instaura mediante os diversos bancos de dados (por isso chamados bancos de memória digital), extensiva ou eletroni-

28 Plano de manência refere-se aqui à permanência do princípio dentro de si em eterna expansão e contração, sem principiar o que quer que seja, de modo que não permanece em relação a este como algo transcendente, emanente ou imanente; nem ainda como transcendental ou hermenêutico. O plano de manência, portanto, conforma-se como a dimensão originária, manente, mais acima aludida (ver nota 22 ), que se expande nos singulares, ao modo do que se poderia designar ser, conceber e haver, e deles se contrai. Caso em que os singulares se apresentam no haver, portanto no ser-outro de ser e conceber, e o abrangente ele mesmo no ser-um destes. Para uma discussão inicial desses elementos, entendidos como modos do abrangente, ver Silva (2014), p. 1099ss. 
camente configurados, espalhados mundo afora, e cujo conceptáculo é a rede noético-digital assim formada. Essa, em outro registro, descrita por Pierre Lévy como a rede que se forja na época do fim do sujeito ou da assim chamada substância pensante, material ou espiritual, "na qual neurônios, módulos cognitivos, humanos, instituições de ensino, línguas, sistema de escrita e computadores se interconectam, transformam e traduzem representações" ${ }^{29}$ mas representações, por sua vez, como lembrara Vattimo, destituídas de realidade objetiva ou de objetividade, no sentido daquilo que constituiria, para os modernos, a realidade em si das $\operatorname{coisas}^{30}$. Enfim, na medida em que os bancos de dados acolhem as imagens digitais então conformadas, a psique em geral e a memória em particular (sensível ou intelectual) se liberam para o exercício o mais pleno de uma vida propriamente livre e criativa.

Tal como em Aristóteles, também aqui, em sua conformação hodierna, o pensar se mostra livre das determinações formais em que a modernidade o encerra; da mesma forma, ele é livre das percepções sensíveis e da imaginação, nas quais ele permanecia confinado, por exemplo, entre os pré-socráticos e os sofistas ${ }^{31}$. Isso significa, nos dias atuais, que o pensar, enquanto pensa em imagens, é então livre do formalismo de um pensamento puramente transcendental, formal e, por conseguinte, oposto à experiência real, concreta; mostra ainda que ele é livre do arbítrio de um pensamento meramente empírico, incapaz de se liberar das impressões sensíveis que o preenchem e com isso encobrem o elemento inteligível das sensações percebidas pelos sentidos. Desse modo, pensar em imagens significa, essencialmente, rememorar o passado e projetar o futuro, no âmbito de uma dimensão na qual o pensar, bem como a imaginação, prescinde das asserções e negações próprias do pensar conceitual, pensando, pois, necessariamente em imagens, contudo, à diferença da percepção sensível e da imaginação, sem confundir pensamento e imagem. Neste sentido, rememorar o passado não quer dizer aqui apenas conservar e lembrar experiências vividas, trazendo-as à memória em vista de um ou de outro fim, como em Aristóteles; mas, para aquém e além disso, consiste em pensar no conservado e no lembrado, sem um uso determinado (ou um fim para outra coisa) das imagens então mobilizadas no ato de pensar. Em assim procedendo, o pensar se permite passar, enfim, do pensar em imagens a um pensar puro, não conceitual e, portanto, não-transcendental; quando, a um tempo, se distingue de um pensar meramente por imagens e, em consequência, não puro, em rigor, impuro ${ }^{32}$.

Desse modo, o pensar em imagens hodierno se distingue tanto do pensar em imagens de Aristóteles, quanto do pensar por imagens de Vattimo. Para o estagirita ${ }^{33}$, na medida em que não há qualquer coisa separada e à parte de grandezas perceptíveis,

29 Lévy (2010), p. 137

30 Ver, a respeito, Vattimo (1992), p. 13; Vattimo (1993), p. 5-6; p. 19ss; p. 110 ss.

31 Veja-se, Aristóteles (2006), III, 3, 427a17ss.

32 Vattimo (2010), p. 13.

33 Veja-se, Aristóteles (2006), III, 8, 432a, 3-14. os inteligíveis estão nas formas perceptíveis de modo tal que nada se aprende nem se compreende sem que se perceba e, portanto, se contemple o aprendido e o compreendido em alguma imagem, a qual é como que uma sensação percebida, mas desprovida de matéria e, por isso, passível de ser preenchida por pensamentos; os quais, por sua vez, não são imagens, mas também não existem sem imagens. Enquanto se pretende, porém, um pensar não conceitual e, assim, não representacional, o pensar em imagens hodierno mantém em comum com o pensar por imagens a recusa da realidade como o dado objetivo - ou em si, em oposição ao subjetivo ou para nós - que está abaixo e para além das imagens ${ }^{34}$, assim como, por conseguinte, do princípio que informa uma tal realidade; ambos, porém, distinguem-se radicalmente quanto à natureza das imagens em cada caso em questão, bem como em relação ao trato com a realidade e ao assim chamado "princípio de realidade". Disso resultam perspectivas teóricas e práticas diversas, em especial no concernente ao pensar por conceitos e às concepções de emancipação ora emergentes; observe-se, a respeito, as seguintes assertivas de Vattimo:

[...]. Se temos uma ideia da realidade, esta, na nossa condição de existência tardo-moderna, não pode ser entendida como o dado objetivo que está abaixo, e para além, das imagens que nos são dadas pelos media. Como e onde poderíamos alcançar uma tal realidade "em si”? Realidade, para nós, é mais o resultado do cruzamento, da "contaminação" (no sentido latino) das múltiplas imagens, interpretações, reconstruções que, em concorrência entre si, seja como for, sem qualquer coordenação central, os media distribuem. [...] na sociedade dos media, ao invés de um ideal de emancipação modelado pela autoconsciência completamente definida, conforme o perfeito conhecimento de quem sabe como estão as coisas [...], abre caminho um ideal de emancipação que tem antes na sua base a oscilação, a pluralidade, e por fim o desgaste do próprio "princípio de realidade". ${ }^{35}$

Tais passagens exprimem o horizonte de sentido de $A$ sociedade transparente, texto publicado originalmente em 1989; nelas é possível observar três aspectos ou elementos constitutivos, que perfazem o chamado pensamento débil, em rigor, o pensar por imagens. Em vista de seu caráter teórico, considere-se os dois primeiros aspectos em conjunto; em seguida, como consequência prática daqueles, o terceiro e último.

O primeiro aspecto a se observar é a natureza midiática das imagens, as quais nos seriam dadas pelos media, que as distribuiriam sem qualquer coordenação central; o segundo consiste no fato de que tais imagens constituiriam, "para nós", a

$\overline{34}$ Ver, Vattimo (1992), p. 13; Vattimo (1993), p. 19ss. Embora tal recusa apareça de modo explícito em Vattimo, ela já aparece na tematização heideggeriana do ser como realidade (Realität). Ver, a respeito, Heidegger, SuZ, § 43, 201ss; 209ss.

35 Vattimo (1992), p. 13 
realidade. Essa, não obstante, assim constituída e, a um tempo, ainda entendida como uma ideia - aqui no sentido de uma representação mental de cujo dado objetivo ou "em si", entretanto, se abriu mão de alcançar, não é, contudo, a rejeição ou o abandono da ideia mesma, mas tão só o enfraquecimento desta; nos termos de Vattimo, o seu retorcimento (Verwindung). Algo levado a termo mediante a extração - ideal -, isto é, a abstração do ser objetivo ou representado, o conceito objetivo ou a objetividade daquela; quer dizer, o conteúdo pelo qual o objeto que ela representa nela comparece ou se manifesta de algum modo; isso implica que a ideia ou a representação perca de vista sua clareza e distinção, logo seu objeto. Quando, de uma ideia, a realidade decai, em rigor, declina a uma imagem; essa, em geral, resultante da abstração do dado objetivo daquela e, em particular, do cruzamento ou da "contaminação" das múltiplas imagens, interpretações ou reconstruções que os media distribuem. Disso resulta pelo menos uma consequência prática importante.

Eis o terceiro e último aspecto, o elemento prático constitutivo do pensar por imagens. Emerso como consequência prática da perspectiva teórica acima apresentada, tal elemento consiste na recusa do ideal de emancipação moderno, pressuposto enquanto fundado em algo como o "princípio de realidade", acima aludido, e então "modelado pela autoconsciência completamente definida, conforme o perfeito conhecimento de quem sabe como estão as coisas" ${ }^{36}$, e na substituição daquele ideal por outro, "que tem antes na sua base a oscilação, a pluralidade, e por fim o desgaste do próprio 'princípio de realidade"”37. Isso se mostra coerente com a recusa da própria ideia de realidade enquanto dado objetivo ou em si e, portanto, do "princípio de realidade" enquanto aquele dado objetivo tomado em sua imobilidade, unidade e indestrutibilidade; contudo, se tal princípio é imóvel, uno e indestrutível, ele só pode ser enfraquecido ou desgastado. Tal enfraquecimento ou desgaste se realiza, enfim, mediante a extração do ser objetivo ou representado da ideia ou da representação mental no ato mesmo do representar, quando estas se fazem imagens e, neste sentido, o conhecimento perde sua objetividade, bem como, por conseguinte, a certeza e a verdade outrora identificadas com a razão ou a autoconsciência universal ela mesma ${ }^{38}$. Dito isso, caberia perguntar: com a proposição de um ideal de emancipação cuja base consiste na oscilação, na pluralidade e no desgaste do "princípio de realidade", portanto, na incerteza, no caráter particular e, enfim, no enfraquecimento desse princípio, haveria de fato, e de direito, emancipação?

Antes de responder a essa questão, é importante reconsiderar o contexto em que ela se nos impõe e, em vista disso, atualizar o estado da mesma. Não vivemos mais numa sociedade dos mass media tradicionais, como essa ainda se mostrava em fins dos anos de 1980, mas numa sociedade digital, em que o controle da informação e da comunicação está literalmente nas mãos, ou antes, nos dedos, ou ainda

36 Vattimo (1992), p. 13

37 Vattimo (1992), p. 13

38 Vattimo (1993), p. 19ss. nos dígitos de quem tem sob si o controle de algum aparato de recolha e transmissão de informações. Quem quer que seja que tenha sob si esse controle, ou qualquer de sua parcela, e exerça adequadamente as funções de recolha e transmissão de informações, constitui-se como um centro gerador de eventos, por conseguinte, também de história e de poder; essa a razão pela qual, em tal sociedade, não mais haver um centro único da história, em rigor, uma história universal condicionada e sustentada por um curso unitário dos eventos ${ }^{39}$. Neste sentido, o pensamento abre-se às múltiplas imagens - inclusive, mas não apenas, aquelas produzidas pelos media tradicionais -, nas quais pensa e se movimenta; são justamente essas múltiplas imagens - do passado, do presente e do futuro - que, ao emergir de diversos centros geradores de eventos, história e poder, condiciona e sustenta os próprios eventos assim gerados.

Isso quer dizer que a própria realidade então se implode, independente da ideia que dela se possa formar, dado que em seu nascedouro ela se constitui em si e para nós como ideia ou, antes, como representação, em suma, como qualidade do real ${ }^{40}$ Este, por conseguinte, considerado nele mesmo, em seu acontecimento singular e, por fim, em sua idiotia $^{41}$, impede toda e qualquer tentativa de qualificação ou de ideação propriamente dita que não seja o seu encobrimento: neste caso, por conceitos, ideias ou, ainda, imagens; essas, tomadas enquanto instrumento do pensar ou como um meio para o pensar e, portanto, o agir e o fazer. Desse modo, as múltiplas imagens assim emersas de diversos centros geradores não implicam meramente a oscilação, a pluralidade e o desgaste de algo como o "princípio de realidade", mas antes a oscilação, o acontecimento plural e, em vista disso, o desgaste do próprio real. Se o que foi dito até aqui está correto, em rigor, não há mais qualquer ideal de emancipação, nem moderno, nem pós-moderno, e muito menos emancipação real; ao contrário, em sentido pleno, ou há ou não há emancipação, a qual não pode ser senão o desgaste mesmo do real. O que significa a liberação do pensamento, e com isso do humano; a saber, a libertação deste em relação ao real e ao ideal, logo, do singular ou do idiotès - do simples fato de existir, do "que", do "Das" ou do "that" - e do universal, do abstrato ou do que é em geral, do "o que", do "Was" ou do "what".

Infelizmente não é possível aqui explicitar mais adequadamente o que na questão mesma se impõe esclarecer; considere-se, no entanto, a liberação acima aludida a partir da conhecida fábula de Hyginus, também chamada o mito do Cuidado (ou do Cura, em latim) ${ }^{42}$. Conforme o mito: o ser humano é feito do humus e deste recebe o seu nome, mas porque o humus pertence à Terra, a esta retornará quando da morte daquele; por receber de Júpiter o

39 Sobre este ponto, confronte-se com Vattimo (1996), p. XV-XVI.

40 Para uma discussão desse problema "em seu nascedouro", veja-se, Scot (1988), p. 230, p. 238-239. Veja-se, ainda, a respeito, Argote (2006), p. 145-180, p. $146-148$

41 Sobre este ponto, ver, Rosset (1977); Rosset (1979).

42 Em SuZ, § 42, 197-198ss, Heidegger se apropria do mito no sentido de apresentar-lhe como uma prova pré-ontológica do Dasein. No que segue, em que pese o caráter já conclusivo dos parágrafos finais da presente seção, 
sopro vital, ao qual este precisa ser devolvido após o desaparecimento de seu possuidor, o homem torna-se então um ser vivo, espiritual; enfim, uma vez que feito pelo Cuidado, este deverá assisti-lo em toda a sua existência. Embora tomado por muitos sob as mais diversas facetas, o mito esconde o fato da subordinação do humano a três instâncias sobre as quais ele não tem nenhum controle, ao passo que elas, de um modo ou de outro, detêm o controle supremo de seu destino; é precisamente dessas três potências que o humano dos tempos pós-modernos intenta libertar-se. Intenta libertar-se da Terra, porque esta é apenas um aspecto de sua constituição dita material, não detendo, pois, o controle total do humo, que se forma de maneira independente dela e, em rigor, apenas em sua superfície, em seu limite, a ela, portanto, não pertencendo de modo próprio. Intenta libertar-se igualmente de Júpiter, aqui representando todos os deuses e o próprio Deus, na medida em que o mesmo ou é apenas uma expressão da natureza ou da Physis ou uma pura e simples representação. Enfim, do próprio Cuidado, enquanto este se lhe apresenta como exterior ou extrínseco.

Em vista disso, a liberação do humano na época pós-moderna implica que o mesmo tenha que assumir seu elemento húmico e dar-se conta de que seu sopro vital se manifesta já pura e simplesmente nesse elemento mesmo, na medida em que ele não pertence à Terra, mas a certa conjunção que foge tanto ao controle desta quanto ao de qualquer deus ou elemento sobrenatural; em consequência, tem ele que necessariamente assumir seu próprio cuidado de si. No mito, interpretado à luz do que até aqui se discutiu, a Terra exprime o real e Júpiter o ideal, sendo o Cuidado, enquanto criador do ser humano, as ideias, conceitos ou imagens por intermédio dos quais ele é ou se faz como tal; se a liberação das duas primeiras instâncias ou potências parece compreensível e, portanto, plausível, ela só poderá ser completa mediante a terceira. Esta, por sua vez, somente se impõe na medida em que o humano singular assume em si e para si as imagens que nele denotam seu existir, bem como conotam o existir de outros singulares, e, assim, nelas os reconhece como casos em que um e mesmo abrangente - no sentido de o-que-é-com - se mostra como o que é a um tempo concreto e comum a todos eles.

Eis aí, enfim, o principal desafio que se impõe ao pensar nas sociedades digitais. A emancipação do humano, para ser plena, não pode se dar mediante um instrumento ou um meio passivo: este o aprisiona em um deixar ser ou acontecer do qual ele mesmo não participa e com isso se limita ao que lhe é dado naquele, mesmo que dele se aproprie ou o deixe apropriar-se de si; aquele o torna ativo e, com isso, livre tão só enquanto o possui e, assim, na verdade o aprisiona. Se, em rigor, o humano não é um universal abstrato ou um conceito determinado - intacto em sua pureza lógica e metafísica ou enfraquecido sob a forma do pensamento débil ou por imagens - aplicável externamente a este ou àquele indivíduo humano, mas tal ou tal indivíduo enquanto um caso do abrangente; então, antes de determinações formais e abstratas, regulado-

mostrar-se-á uma interpretação ligeiramente distinta da de Heidegger, calcada na distinção entre o pensar em imagens e o pensar por imagens. ras do fenômeno humano, há que se pensar em determinações abrangentes e concretas. Estas, à diferença daquelas, não subordinam o pensamento a conceitos abstraídos de casos empíricos determinados e assim formalmente aplicáveis a casos diversos; ao contrário, ao reconhecer que o pensar, para ser concreto, tem que pensar em imagens, e não apenas por imagens, deixa-o livre para conformar-se nelas, e não por elas, segundo modos de ser e de conceber próprios do indivíduo em sua relação consigo mesmo e com os outros. Em vista disso, tais modos resultam do pensar apenas enquanto este pensa em imagens e, portanto, praticamente; pois somente enquanto prático pode o pensar emancipar-se e compreender o acontecimento plural, bem como os conflitos daí resultantes; nos quais intervém, necessariamente, de um modo ou de outro.

\section{Considerações finais}

O pensar em imagens é um pensamento concreto, que não permanece em si, mas se projeta na ação; na qual se expande e se contrai. É precisamente esse processo que o permite manter-se dentro de si e, a um tempo, ativo. Em vista disso, ele é igualmente pensamento puro; porque opera sem nenhum instrumento ou meio, interior ou exterior, assim como sem instrumentalizar as imagens nas quais se plasma, sem transformá-las em espécies inteligíveis ou representações para, a partir destas, voltar-se à forma que se move naquelas. Enquanto ato de ser da coisa, a forma se mostra como o próprio pensar, que, na coisa, como elemento estruturante desta, ao informá-la, ou nela expandir-se, informa-se a si mesmo de modo a contrair-se dentro de si e, então, contemplar a si próprio.

Mediante tal configuração, o pensar em imagens não opera nem conforme a intuição abstrativa dos antigos, nem segundo a representação dos modernos. Em vista disso, deixa para trás a liberdade formal da autoconsciência plenamente cônscia do espírito certo de si destes e a segurança da comunidade ou do cosmos natural daqueles. $\mathrm{O}$ que para ele e nele implica ser livre, bem como levar a termo o reconhecimento desse modo de ser, assumindo-o enquanto o-que-é-comum a todos os indivíduos que assim se reconhecem mutuamente, permanece a um tempo aquém e além de toda intuição e de toda representação; portanto de todo e qualquer separação de ser e conceber, pensar e agir etc. Isso significa que o pensar em imagens não é uma atividade da inteligência em oposição aos sentidos, algo da intelecção em oposição à sensação; mas antes, enfim, que ele é ou está aquém e além dessa oposição, em suma, no abrangente.

Essa a manifestação de um novo início do pensar e o ponto de partida de uma nova concepção de emancipação. Os quais, para serem alcançados e então propriamente praticados, exigem tão só que o singular se despoje das determinações formais ou dos conceitos abstratos e das imagens que se lhe impõem como instrumentos ou meios para ser e conceber-se a si mesmo enquanto livre. Algo oscilante porque livre e, por isso, em vista de cumprir-se unicamente por reconhecimento. 


\section{Referências}

Argote, G.M. (2006). "Realidad”, Historia de una palabra desde sus orígenes latinos hasta Zubiri. In Cuadernos Salmantinos de Filosofia, 33, p. 145180.

Aristote (1952). Physique (I-IV). Paris: Les Belles Lettres.

Aristóteles (2006). De anima. Apresentação, tradução e notas de Maria Cecília Gomes dos Reis. Rio de Janeiro: Editora 34

Boulnois, O (2008). Au-delà de l'image. Une archéologie du visuel au Moyen Âge (Ve-XVIe siècle). Paris: Éditions du Seuil.

Eco, U. (2010). L'antiporfirio. In G. Vattimo \& P. A. Rovatti. Il pensiero debole (p. 52-80). Feltrinelli.

Eco, U. (1992). Los límites de la interpretación. Barcelona: Lumen.

Florido, F. L. (2000). Una estructura filosófica en Historia de la Filosofía. In Anales del Seminario de Historia de la Filosofía. Vol. 17, p. 195-216.

Hartmann, N. (1964). Aristóteles y el problema del concepto; sobre la doctrina del eidos em Platón y Aristóteles. México/DF: Centro de Estudios filosóficos (UNAM).

Hegel, G. W. F. (2003). Fenomenologia do espírito. Tradução de Paulo Meneses. 2. ed. São Paulo: Loyola.

Hegel, G. W. F. (1988). Phänomenologie des Geistes, neu hrsg. von Hans-Friedrich Wessels u. Heirinch Clairmont. Mit e. Einleitung von Wolfgang Bonsiepen. Hamburg: Meiner (Original de 1807).

Heidegger, M. (2012). Ser e tempo. Edição em alemão e português. Tradução de Fausto Castilho. Campinas, SP: Editora Unicamp; Petrópolis, RJ: Vozes.

Heidegger, M. (1978). Gesammtausgabe, I. Frühe Schriften. Frankfurt am Main: Vittorio Klostermann.

Kemmerling, A. (2003). Die erste moderne Konzeption mentaler Repräsentation. In U Meixner \& A. Newen (Hrsg.). Seele, Denken, Bewusstsein (p. 153-196). Berlin; New York: Walter de Gruyter.

Lévy, P. (2010). As tecnologias da Inteligência - O futuro do pensamento na era da informática. Tradução de Carlos Irineu da Costa. 2. ed. São Paulo: Editora 34.

Mac Dowell, J. A. (1993). A gênese da ontologia fundamental de M. Heidegger. São Paulo: Loyola.

Merlan, P. (1975). From Platonism to Neoplatonism. Third edition, revised, Hague: Martinus Nijhof.
Muralt, A. de (2008). La apuesta de la filosofía medieval. Estudios tomistas, escotistas ockmistas y gregorianos. Madrid: Maercial Pons.

Platon (1950). Le sophiste. Texte établi et traduit par Auguste Diès. Paris: Les Belles Lettres.

Rorty, R. (1994). A filosofia e o espelho da natureza. Rio de Janeiro: Relume Dumará.

Rosset, C. (1979). L'objet singulier. Nouvelle édition augmentée. Paris: Minuit.

Rosset, C. (1977). Le réel. Traité de l'idiotie. Paris: Minuit.

Scot, D. (1993). L'Image. Introduction, traduction et notes par G. Sondag. Paris: Vrin.

Scot, D. (1988). Sur la connaissance de Dieu et l'univocité de l'étant. Introduction, traduction et commentaire par Olivier Boulnois. Paris: PUF.

Scuri, A. E. (2002). Fundamentos da imagem digital. Rio de Janeiro. Disponível em: http://www.tecgraf.puc-rio.br/ scuri/download/fid.pdf

Silva, M. M. da (2016). O problema do início e a questão do Abrangente. Linhas fundamentais de uma metafísica pós-moderna. In SILVA, M. M. DA (Org.). Ser e pensar, inícios. São Paulo: Todas as Musas.

Silva, M. M. da (2014). Proposição pós-moderna do idealismo especulativo puro. Uma intervenção no confronto de Heidegger e Schelling versus Hegel. In Ferreiro, H; Hoffman, T.S. \& Bavaresco, A. (Orgs). Los aportes del itinerario intelectual de Kant a Hegel; Os aportes do itinerário intelectual de Kant a Hegel. Porto Alegre: Edipucrs; Editora $\mathrm{Fi}$

Vattimo, G. (2010). Dialettica, differenza, pensiero debole. In G. Vattimo \& P. A. Rovatti. Il pensiero debole. Feltrinelli, p. 12-28.

Vattimo, G. (1996). O fim da modernidade. Trad. Eduardo Brandão. São Paulo: Martins Fontes.

Vattimo, G. (1993). The Adventure of the Difference, Baltimore, Maryland: The John Hopkins University Press.

Vattimo, G. (1992). A sociedade transparente. Trad. Hossein Shooja e Isabel Santos. Lisboa: Relógio D’Água. 
Manuel Moreira da Silva é Doutor em Filosofia pela Universidade Estadual de Campinas, possui ainda Licenciatura, Bacharelado e Mestrado em Filosofia pela Universidade Federal de Minas Gerais; Psicanalista (em formação) pela Sociedade Psicanalítica do Paraná (SPP). Atualmente é Professor Adjunto D da Universidade Estadual do Centro-Oeste (Guarapuava/PR), na qual desenvolve pesquisa continuada (PqC) em torno do problema da metafísica como ciência e como modo de vida na época atual, do pensar na pós-modernidade e da emergência de uma metafísica pós-moderna; neste caso, mais propriamente, busca repropor a assim chamada filosofia especulativa pura sob a forma de uma filosofia da manência, a partir do diálogo e do confronto com filósofos como Proclo, Bruno, Schelling, Hegel e Heidegger entre outros. $\mathrm{Na}$ perspectiva da determinação dos elementos estruturantes fundamentais da metafísica pósmoderna, investiga em detalhe as noções de Início (Arché, Princípio), Abrangente (Katholou, das Umgreifende, Encompassing), Manência (Moné), Expansão, Contração, Ser, Conceber e Haver entre outras. Investiga ainda em que medida a Psicanálise pode se mostrar como abertura à instauração de uma metafísica pós-moderna e, em vista disso, em que medidaMetafísicaePsicanálise podem serentendidas, a um tempo, como ciência e como modo de vida, mais propriamente como vida ética ou do espírito, entendida por sua vez como exercício espiritual. Tem experiência na área de Filosofia, com ênfase em Metafísica, Teoria do Conhecimento, Ética, Filosofia do Direito e Psicanálise. Atua principalmente nos seguintes temas: Hegel, Idealismo alemão, Tradição neoplatônica, Fenomenologia do Espírito, Ciência da Lógica. Sistema de Hegel. Aristóteles. Pensar em imagens. Abrangente (Katholou). Proclo. Filosofia da Manência. Psicanálise. Freud. Lacan

Recebido em 26.03.2017

Primeira Decisão Editorial em 17.06.2017

Aceito em 02.05.2018 